\title{
Morphological and Nutritional Evaluation of Some Conserved Folk Rice Genotypes to Fight Back Against Micronutrient Deficiency
}

\author{
Sanjoy Kumar Bordolui*, R. L. Moharana and P. Chattopadhyay \\ ${ }^{1}$ Department of Seed Science and Technology, Bidhan Chandra Krishi Viswavidyalaya, \\ Mohanpur, Nadia, West Bengal, India \\ ${ }^{2}$ Department of Seed Sci. \& Tech., College of Agriculture, Bhawanipatna, \\ OUAT, Orissa, India \\ *Corresponding author
}

\begin{tabular}{l} 
K e y w o r d s \\
$\begin{array}{l}\text { Folk rice, Iron, } \\
\text { Zinc, Calcium, } \\
\text { Bio-diversity }\end{array}$ \\
\hline Article Info \\
$\begin{array}{l}\text { Accepted: } \\
\text { 12 December } 2020 \\
\text { Available Online: } \\
\text { 10 January } 2021\end{array}$ \\
\hline
\end{tabular}

Throughout the world more than 2 billion people affect due to micronutrient deficiency or hidden hunger, among them women and children put up with more because of their physiological needs. Impaired immune function, complications in pregnancy and childbirth, poor child growth as well as learning disability happen due to Iron and zinc deficiencies. Rice is the staple food of more than half the world's population and since ancient time it is being cultivated in Asia. Considering the importance of rice as dietary source and to fight back against micronutrient deficiency, in the present study the $\mathrm{Zn}$, Fe and $\mathrm{Ca}$ content has been analyzed in 45 different folk rice along with some HYVs and hybrid rice. Out of the 45 different folk rice genotypes 25 were aromatic and 20 were non-aromatic in nature. These were evaluated with three high yielding varieties and two hybrid varieties to determine ways to conserve these indigenous genotypes ex-situ in active participation of such experienced farmers at Gontra village, Chakdah, Nadia, West Bengal. All the genotypes were evaluated during kharif season of 2017 and 2018 in Randamised Block Design in three replications following standard agronomic practices. Seed yield among the indigenous genotypes ranged from $227.33 \mathrm{~g} \mathrm{~m}^{-2}$ (Tulsimanjari) to $550 \mathrm{~g} \mathrm{~m}^{-2}$ (Chamarmani). Other genotypes which recorded comparatively superior performance were Sitashal $\left(525.17 \mathrm{~g} \mathrm{~m}^{-2}\right)$, Kedargouri $\left(525.33 \mathrm{~g} \mathrm{~m}^{-2}\right)$, Tilakkati (514 $\left.\mathrm{g} \mathrm{m}^{-2}\right)$, Langalmuthi (513.07 $\left.\mathrm{gm}^{-2}\right)$, Dudkhas (508.33 $\left.\mathrm{g} \mathrm{m}^{-2}\right)$, Dadshal $\left(497 \mathrm{~g} \mathrm{~m}^{-2}\right)$, Kalma (485.33 $\left.\mathrm{g} \mathrm{m}^{-2}\right)$, Kanakchur $\left(471 \mathrm{~g} \mathrm{~m}^{-2}\right)$, Tulaipanji $\left(471.67 \mathrm{~g} \mathrm{~m}^{-2}\right)$, Chinikamini (462 $\mathrm{g} \mathrm{m}^{-}$ $\left.{ }^{2}\right)$, Chinigura (459.33 $\left.\mathrm{g} \mathrm{m}^{-2}\right)$, Chinapakri $\left(485 \mathrm{~g} \mathrm{~m}^{-2}\right)$. The standard semi-dwarf check variety IET-4786 (Satabdi) and IET-4094 (Kshitish) recorded 602.33 and $608.33 \mathrm{~g} \mathrm{~m}^{-2}$. Morphological analysis revealed that among the tested genotypes the length varied from $5.13 \mathrm{~mm}$ to 10.13 $\mathrm{mm}$, the breadth varied from $1.50 \mathrm{~mm}$ to $3.40 \mathrm{~mm}$. Common cultivars contain about $12 \mathrm{mg} \mathrm{Fe}$ $\mathrm{kg}^{-1}$ and around $25 \mathrm{mg} \mathrm{Zn} \mathrm{kg}{ }^{-1}$ but some traditional varieties were found to possess those micronutrients in double amounts. It is interesting to note that the indigenous genotypes were rich in micro-nutrient compared to HYVs and hybrids tested in the study. Highest iron contents was found in Sonajhuli (70.30ppm) whereas highest calcium content was revealed in Chinigura (196.75ppm) and highest zinc content was recorded in Raghushal (26.45ppm). It is suggested that the indigenous genotypes having considerably high micro-nutrients like Fe, $\mathrm{Zn}$, Ca may be considered as high value rice genotypes. The potentiality of these genotypes might be exploited further due to its commercial importance or through the utilization of their gene pool in the area of plant breeding to combat the hidden hunger. 


\section{Introduction}

Rice is the staple food of more than half the world's population and has been cultivated in Asia since ancient time generation after generation. The farmers have conserved thousands of different varieties (Jackson, 1997) and these landraces, together with the 22 pantropical, wild species of Oryza, are the genetic base for the breeding efforts to increase the productivity of rice and sustain it. Besides the landrace varieties and wild species, the genetic resources of rice also include the natural hybrids and a range of different genetic stocks comprising commercial and absolute varieties (Biswas et al., 2020). The ability to consistently produce improved varieties depends on availability of broad base of germplasm from which desirable characteristics can be selected. However, in this regards the erosion of agrobiodiversity often signals that continued availability can no longer be taken for granted. Nevertheless agro-biodiversity is a much larger issue, particularly the conservation part, both exsitu and insitu situation (Bordolui et al., 2006a). In any breeding effort these diversity are important because the choice of genotype from such crop diversity is key to the improvement of that crop (Bordolui et al., 2006b). While we can readily identify uses of biodiversity which directly support human life and commercial value we often overlook a most of hidden values which are equally important to human life. The value of micro nutrient in rice germplasm can be of considerable concern. In India, over 6,000 children below the age of five die every day mainly due to the lack of basic micronutrients like Vitamin A, iron, iodine, zinc and folic acid in their diet. An estimated 50,000 children are born deformed each year due to various vitamin and mineral deficiencies, according to studies (Lettington, 2001). The prevalence of iron deficiency is estimated to be about $30 \%$ o the world population [WHO (1992)1], making iron by far the most widespread nutrient deficiency world-wide. In rice the problem of micro nutrient deficiency are of considerable importance, rice seeds, which are usually milled to remove the oil-rich aleurone layer that turns rancid upon storage, are distinguished by a very low content of iron (between $0.2 \mathrm{mg}$ and $6.8 \mathrm{mg}$ per $100 \mathrm{~g}$ rice) and by its very low bioavailability. Spence $e t$ al., (1991) had been attempts to increase the iron content with the introduction of the ferritin gene from Phaseolus vulgaris. Pasamontes et al., (1997) reported that thermo-tolerant phytase from Aspergillus fumigatus to over-express the endogenous cysteine-rich metallothionein-like protein. At IRRI Gregorio et al., (2002) have been evaluating the genetic variability of $\mathrm{Fe}$ and $\mathrm{Zn}$ concentrations within the genotypes tested, suggesting the genetic potential of increasing the concentration of these micronutrients in rice and these lines also had the highest grain of $\mathrm{Zn}$ concentration $\left(24-33 \mathrm{mg} \mathrm{Kg}^{-1}\right)$. It was also exhibited that aromatic trait was pleiotropic for grain of $\mathrm{Fe}$ or $\mathrm{Zn}$ concentrations, and therefore, this trait could be well applied for selection of rice genotypes with high $\mathrm{Zn}$ and Fe levels. A high iron trait can be confined with high yielding trait (Chakraborty et al., 2020). This has been demonstrated in an improved line IR68144$3 b-2-2-3$ of rice developed at IRRI (Gregorrio, 2002). It is interesting that this report also indicated that in their experiments, the aromatic rice was consistently higher in grain of $\mathrm{Fe}$ and/or $\mathrm{Zn}$ concentration than their non-aromatic counter parts (Hsieh et al., 1995). With the above considerations, the present investigation has been undertaken to evaluate a collection of 25 aromatic genotypes, 20 non-aromatic genotypes, 3 high yielding varieties and 2 hybrid varieties of rice and document their various seed quality parameters including nutritional qualities and determine ways to conserve these indigenous 
genotypes $e x$-situ with active participation of the farmers. The objectives of study were to compare indigenous genotypes with high yielding and hybrid varieties with reference to their morphological and bio-chemical characteristics and to select and identify superior genotypes for its commercial utilization.

\section{Materials and Methods}

Twenty five aromatic genotypes, twenty nonaromatic genotypes, three high yielding varieties and two hybrid varieties of rice were raised during Kharif season 2017 and 2018 at Gontra village, Chakdah, Nadia, West Bengal. In that new alluvial soil having at ph 7.07, organic carbon $0.8 \%$ soil type clay loam, EC $0.7 \mathrm{~m} \mathrm{mhs} \mathrm{cm}^{-2}$, available nitrogen $222.6 \mathrm{~kg}$ ha $^{-1}$, phosphorus $24.3 \mathrm{~kg}$ and potassium 189.7 $\mathrm{kg} \mathrm{ha}{ }^{-1}$. Seedlings were raised in individual plots following standard agronomic practices and intercultural operations in the plot, 30 days old seedlings (one per hill) were transplanted in the experimental plots with three replications following Randomised Block Design. Spacing was $20 \mathrm{~cm}$ between the rows, $15 \mathrm{~cm}$ between the plants and $50 \mathrm{~cm}$ between the two plots. Each plot was $2 \mathrm{~m}$ length and $1 \mathrm{~m}$ breadth.

Fertilizer was applied in both the years as per standard recommendation. Field observation was taken on seed yield both the years. Laboratory experiment was carried out to elucidate the morphological and nutritional value $(\mathrm{Zn}, \mathrm{Fe}$ and $\mathrm{Ca}$ ) of those fifty rice genotypes at Seed testing laboratory and soil testing laboratory, BCKV, West Bengal during 2018. Observations were recorded on Seed length $(\mathrm{mm})$, seed breadth $(\mathrm{mm})$, seed thickness $(\mathrm{mm})$, kernel length $(\mathrm{mm})$, kernel breadth $(\mathrm{mm})$, kernel thickness $(\mathrm{mm}), \mathrm{Zn}$ (ppm), $\mathrm{Fe}(\mathrm{ppm})$ and $\mathrm{Ca}(\mathrm{ppm})$ of these rice genotypes.

\section{Determination of Ca through Atomic Absorption Spectro Photometer Method}

Diluate digest of dry ashing as 1:100 with the La-diluant (Add 6.235 gm $\mathrm{La}\left(\mathrm{NO}_{3}\right), \mathrm{H}_{2} \mathrm{O}$ in $900 \mathrm{ml}$ distilled water, make volume up to 1 liter, if nitric-perchloric acid digest is used, diluate it as 1:20). Then prepare standard either singly or in one solution. 0 to $3 \mathrm{mg} \mathrm{K} / \mathrm{L}$; 0 to $0.3 \mathrm{mg} / \mathrm{L}$ in a $2000 \mathrm{mg} \mathrm{La} / \mathrm{L}$ solution and read with AAS using an acetylene-air flame and condition given for the particular element in operator's manual. The amount of $\mathrm{Ca}$ (ppm) in seed tissue was calculated by AAS reading $\left(\mathrm{mg} \mathrm{L}^{-1}\right) \mathrm{x}$ diluation / 10000. (Where, diluation $=$ Original dilution $\mathrm{X}$ final dilution $=$ $20 \times 100$ (for dry ash digest)

\section{Determination of $\mathrm{Fe}$ and $\mathrm{Zn}$ through Atomic Absorption Spectro Photometer Method}

Half a gram of powdered rice seeds sample with $5 \mathrm{ml}$ of di-acid mixture (9:4 Nitric acid:Parchloric acid) was kept for overnight digestion. The digested samples were kept on a hot plate till solution turned colourless. The extract was diluted to $100 \mathrm{ml}$ and fed to the Atomic Absorption Spectrophotometer. The concentration was expressed in ppm. The amount of Fe or $\mathrm{Zn}$ was calculated by Actual reading multiplied with dilution (Here dilution $=200$, because $0.5 \mathrm{gm}$ plant sample in $100 \mathrm{ml}$ )

\section{Results and Discussion}

The immense genetic diversity rice landraces is similarly reflected by the multiplicity of nutritional characteristics. Appropriate rice varieties exist for enhancing the supply of various nutrients, including protein and certain minerals. Some genotypes may even be evaluated by a combination of favorable nutritional traits. More synergies between nutritional components may exist and have to 
be clarified in further scientific work. The diversity of such favourable nutritional characteristics is not represented in the most wide-spread high yielding varieties currently prevailing in Asian rice cultivation. These have been evolved mainly to enhance the quantitative yields, and not the nutritional value. The high nutritional quality of indigenous rice can form a solid basis for changing priorities in rice breeding, putting more emphasis on the grain nutritional value. Modern conventional breeding techniques, including molecular marker-assisted selection, may be very helpful in accelerating the development of more nutritious rice varieties. Combining high yields and high grain nutritional value thus emerges to be possible without any genetic manipulation.

Table.1 Seed, kernel characters and yield performance of some rice genotypes

\begin{tabular}{|c|c|c|c|c|c|c|c|c|}
\hline \multirow{2}{*}{$\begin{array}{l}\text { Sl. } \\
\text { No. }\end{array}$} & \multirow{2}{*}{$\begin{array}{l}\text { Name of the } \\
\text { genotypes }\end{array}$} & \multicolumn{3}{|c|}{ Seed } & \multicolumn{3}{|c|}{ kernel } & \multirow{2}{*}{$\begin{array}{l}\text { Yield } \\
\left(\mathrm{g} \mathrm{m}^{-1}\right)\end{array}$} \\
\hline & & $\begin{array}{c}\text { Length } \\
(\mathbf{m m})\end{array}$ & $\begin{array}{c}\text { Breadth } \\
(\mathbf{m m})\end{array}$ & $\begin{array}{l}\text { Thickness } \\
\text { (mm) }\end{array}$ & $\begin{array}{l}\text { Length } \\
\text { (mm) }\end{array}$ & $\begin{array}{c}\text { Breadth } \\
\text { (mm) }\end{array}$ & $\begin{array}{l}\text { Thickness } \\
\text { (mm) }\end{array}$ & \\
\hline 1 & Danaguri & 5.77 & 1.50 & 1.45 & 4.13 & 1.37 & 1.30 & 340.33 \\
\hline 2 & Kalonunia & 7.47 & 1.77 & 1.76 & 5.57 & 1.53 & 1.54 & 346.00 \\
\hline 3 & Badshabhog & 5.93 & 1.95 & 1.68 & 3.80 & 1.62 & 1.26 & 324.67 \\
\hline 4 & Gobindobhog & 6.50 & 1.92 & 1.55 & 4.14 & 1.75 & 1.63 & 300.33 \\
\hline 5 & Tulsimanjari & 6.63 & 2.10 & 1.87 & 4.50 & 1.73 & 1.64 & 227.33 \\
\hline 6 & Gopalbhog & 5.90 & 1.97 & 1.88 & 4.30 & 1.85 & 1.69 & 257.33 \\
\hline 7 & Khaskani & 6.73 & 2.07 & 1.81 & 4.93 & 1.80 & 1.60 & 318.00 \\
\hline 8 & Radhunipagal & 6.70 & 2.23 & 1.85 & 4.20 & 1.75 & 1.69 & 240.33 \\
\hline 9 & Mohanbhog & 5.87 & 1.90 & 1.74 & 4.50 & 1.80 & 1.53 & 240.67 \\
\hline 10 & Agulha & 10.13 & 2.12 & 1.90 & 7.70 & 1.97 & 1.63 & 403.67 \\
\hline 11 & Gayasur & 6.90 & 2.78 & 1.93 & 6.30 & 2.52 & 1.49 & 393.67 \\
\hline 12 & Kalojira & 7.60 & 2.12 & 1.77 & 5.70 & 1.79 & 1.56 & 374.67 \\
\hline 13 & Fulpakri & 6.40 & 1.85 & 1.57 & 4.58 & 1.75 & 1.33 & 383.67 \\
\hline 14 & Rupsail & 7.41 & 1.82 & 1.78 & 5.48 & 1.52 & 1.56 & 251.00 \\
\hline 15 & Sonajhuli & 6.06 & 1.94 & 1.76 & 3.90 & 1.61 & 1.28 & 354.33 \\
\hline 16 & Chinapakri & 6.35 & 2.11 & 1.87 & 4.21 & 1.75 & 1.67 & 485.00 \\
\hline 17 & Pakri & 6.55 & 2.14 & 1.87 & 4.38 & 1.73 & 1.67 & 400.67 \\
\hline 18 & Raghushal & 6.12 & 2.02 & 1.88 & 4.20 & 1.86 & 1.65 & 384.33 \\
\hline 19 & Chamarmani & 6.80 & 2.01 & 1.75 & 4.40 & 1.75 & 1.63 & 550.00 \\
\hline 20 & Sitashal & 6.20 & 2.26 & 1.85 & 4.25 & 1.77 & 1.68 & 525.17 \\
\hline 21 & Dudherswar & 6.21 & 1.98 & 1.73 & 4.50 & 1.79 & 1.52 & 401.33 \\
\hline 22 & Jamainadu & 8.00 & 2.08 & 1.86 & 5.90 & 1.72 & 1.66 & 292.83 \\
\hline 23 & Langalmuthi & 7.01 & 2.72 & 1.73 & 6.03 & 1.89 & 1.48 & 513.07 \\
\hline 24 & Suanagra & 7.61 & 2.14 & 1.76 & 5.75 & 1.79 & 1.57 & 424.00 \\
\hline 25 & Hamilton & 7.69 & 2.15 & 1.87 & 5.55 & 1.95 & 1.62 & 449.33 \\
\hline 26 & Mocha & 9.05 & 2.85 & 1.97 & 6.73 & 2.00 & 1.83 & 414.67 \\
\hline 27 & Tilakkati & 9.10 & 3.03 & 2.08 & 7.15 & 2.81 & 1.86 & 514.33 \\
\hline 28 & Khejurchari & 7.62 & 1.91 & 1.77 & 5.37 & 2.88 & 1.53 & 435.33 \\
\hline 29 & Vasamanik & 8.37 & 2.69 & 1.96 & 5.87 & 1.97 & 1.77 & 383.67 \\
\hline
\end{tabular}




\begin{tabular}{|r|l|c|c|c|c|c|c|c|}
\hline $\mathbf{3 0}$ & Jugal & 8.77 & 2.34 & 1.85 & 6.30 & 1.89 & 1.74 & 540.67 \\
\hline $\mathbf{3 1}$ & Kalma & 8.64 & 2.17 & 1.87 & 6.43 & 1.88 & 1.72 & 485.33 \\
\hline $\mathbf{3 2}$ & Tulsiphenu & 5.75 & 2.06 & 1.86 & 5.00 & 1.70 & 1.65 & 295.33 \\
\hline $\mathbf{3 3}$ & BR-34 & 5.55 & 2.08 & 1.81 & 4.30 & 1.80 & 1.65 & 382.33 \\
\hline $\mathbf{3 4}$ & Parbatjira & 5.13 & 2.05 & 1.55 & 3.90 & 1.89 & 1.48 & 403.67 \\
\hline $\mathbf{3 5}$ & Chinigura & 7.84 & 2.95 & 2.54 & 5.80 & 2.25 & 1.83 & 459.33 \\
\hline $\mathbf{3 6}$ & Kalijira & 9.82 & 2.39 & 1.89 & 7.23 & 1.90 & 1.65 & 376.67 \\
\hline $\mathbf{3 7}$ & Tulaipanji & 5.30 & 2.50 & 2.08 & 4.33 & 2.07 & 1.88 & 471.67 \\
\hline $\mathbf{3 8}$ & Kalijoha & 7.75 & 2.71 & 2.15 & 5.80 & 2.65 & 1.89 & 354.00 \\
\hline $\mathbf{3 9}$ & IET13544 & 8.93 & 3.40 & 2.20 & 7.15 & 2.92 & 1.79 & 406.67 \\
\hline $\mathbf{4 0}$ & Chinikamini & 8.50 & 2.61 & 1.81 & 6.17 & 2.15 & 1.58 & 462.00 \\
\hline $\mathbf{4 1}$ & Kedargouri & 7.65 & 2.35 & 1.80 & 6.80 & 2.10 & 1.45 & 525.33 \\
\hline $\mathbf{4 2}$ & Dudkhas & 7.96 & 3.35 & 2.03 & 7.35 & 2.92 & 1.79 & 508.33 \\
\hline $\mathbf{4 3}$ & Dadshal & 5.76 & 2.07 & 1.86 & 3.64 & 1.81 & 1.63 & 497.00 \\
\hline $\mathbf{4 4}$ & Gangajali & 10.05 & 2.57 & 1.75 & 6.83 & 2.00 & 1.64 & 439.33 \\
\hline $\mathbf{4 5}$ & Kanakchur & 6.67 & 2.50 & 1.85 & 5.27 & 2.13 & 1.64 & 471.00 \\
\hline $\mathbf{4 6}$ & IR-36 & 10.03 & 2.83 & 1.87 & 5.00 & 1.90 & 1.60 & 518.67 \\
\hline $\mathbf{4 7}$ & IET-4094 & 10.10 & 2.57 & 1.73 & 6.97 & 1.90 & 1.61 & 608.33 \\
\hline $\mathbf{4 8}$ & IET-4786 & 10.07 & 2.10 & 1.77 & 5.23 & 1.89 & 1.61 & 602.33 \\
\hline $\mathbf{4 9}$ & CNHR-7 & 9.87 & 2.70 & 1.77 & 5.27 & 1.91 & 1.60 & 708.67 \\
\hline $\mathbf{5 0}$ & PHB-71 & 9.87 & 2.40 & 1.43 & 5.27 & 1.95 & 1.59 & 711.00 \\
\hline Grand mean & $\mathbf{7 . 4 7 3 2}$ & $\mathbf{2 . 3 0 2 1}$ & $\mathbf{1 . 8 3 6 1}$ & $\mathbf{5 . 3 3 6 7}$ & $\mathbf{1 . 9 4 1 3}$ & $\mathbf{1 . 6 1 7 6}$ & $\mathbf{4 2 6 . 1 5}$ \\
\hline SEm $(\mathbf{\pm})$ & $\mathbf{0 . 1 6 2 7}$ & $\mathbf{0 . 0 5 8 1}$ & $\mathbf{0 . 0 9 6 7}$ & $\mathbf{0 . 2 8 5 4}$ & $\mathbf{0 . 0 4 7 5}$ & $\mathbf{0 . 0 2 4 1}$ & $\mathbf{7 . 6 4 6 2}$ \\
\hline LSD $(\mathbf{0 . 0 5 )}$ & $\mathbf{0 . 4 7 2 1}$ & $\mathbf{0 . 1 5 4 9}$ & $\mathbf{0 . 2 6 1 5}$ & $\mathbf{0 . 6 6 5 1}$ & $\mathbf{0 . 1 2 1 4}$ & $\mathbf{0 . 0 6 7 8}$ & $\mathbf{2 0 . 1 3 9}$ \\
\hline
\end{tabular}

Table.2 Zn, Fe and Ca contents of some rice genotypes

\begin{tabular}{|c|l|c|c|c|c|}
\hline $\begin{array}{c}\text { Sl. } \\
\text { No. }\end{array}$ & $\begin{array}{c}\text { Name of the } \\
\text { genotypes }\end{array}$ & Desirable trait (s) & Zn (ppm) & Fe (ppm) & Ca (ppm) \\
\hline $\mathbf{1}$ & Danaguri & Small grain, high aroma & 16.43 & 25.53 & 110.86 \\
\hline $\mathbf{2}$ & Kalonunia & Small grain, high aroma & 26.42 & 38.97 & 144.48 \\
\hline $\mathbf{3}$ & Badshabhog & Small grain, high aroma & 21.75 & 25.33 & 141.28 \\
\hline $\mathbf{4}$ & Gobindobhog & Small grain, high aroma & 18.23 & 21.00 & 175.65 \\
\hline $\mathbf{5}$ & Tulsimanjari & Small grain, high aroma & 15.60 & 50.10 & 156.51 \\
\hline $\mathbf{6}$ & Gopalbhog & Small grain, high aroma & 18.83 & 25.57 & 147.70 \\
\hline $\mathbf{7}$ & Khaskani & Quality parboiled rice & 21.10 & 20.30 & 129.27 \\
\hline $\mathbf{8}$ & Radhunipagal & Small grain, high aroma & 17.63 & 32.70 & 121.74 \\
\hline $\mathbf{9}$ & Mohanbhog & Small grain, high aroma & 15.77 & 23.70 & 114.38 \\
\hline $\mathbf{1 0}$ & Agulha & Quality parboiled rice & 15.47 & 21.13 & 171.44 \\
\hline $\mathbf{1 1}$ & Gayasur & Quality parboiled rice & 14.40 & 56.40 & 150.34 \\
\hline $\mathbf{1 2}$ & Kalojira & Small grain, high aroma & 19.50 & 23.30 & 110.90 \\
\hline $\mathbf{1 3}$ & Fulpakri & Quality parboiled rice & 14.73 & 41.03 & 156.81 \\
\hline
\end{tabular}




\begin{tabular}{|c|c|c|c|c|c|}
\hline 14 & Rupsail & Quality parboiled rice & 20.33 & 64.83 & 123.17 \\
\hline 15 & Sonajhuli & Quality parboiled rice & 21.50 & 70.30 & 153.80 \\
\hline 16 & Chinapakri & Quality parboiled rice & 22.72 & 56.60 & 122.96 \\
\hline 17 & Pakri & Quality parboiled rice & 25.48 & 52.03 & 128.96 \\
\hline 18 & Raghushal & Quality parboiled rice & 26.45 & 47.87 & 126.39 \\
\hline 19 & Chamarmani & Quality parboiled rice & 23.47 & 63.60 & 157.05 \\
\hline 20 & Sitashal & Quality parboiled rice & 21.03 & 43.37 & 120.23 \\
\hline 21 & Dudheswar & Quality parboiled rice & 23.05 & 56.30 & 187.63 \\
\hline 22 & Jamainadu & Quality parboiled rice & 21.78 & 58.53 & 156.83 \\
\hline 23 & Langalmuthi & Quality parboiled rice & 25.10 & 64.97 & 119.91 \\
\hline 24 & Suanagra & Quality parboiled rice & 23.23 & 56.60 & 181.56 \\
\hline 25 & Hamilton & Quality parboiled rice & 23.47 & 65.73 & 172.24 \\
\hline 26 & Mocha & Quality parboiled rice & 18.53 & 47.50 & 123.13 \\
\hline 27 & Tilakkati & Quality parboiled rice & 22.48 & 35.70 & 175.58 \\
\hline 28 & Khejurchari & Quality parboiled rice & 20.53 & 39.00 & 116.85 \\
\hline 29 & Vasamanik & Quality parboiled rice & 21.77 & 34.90 & 187.93 \\
\hline 30 & Jugal & Quality parboiled rice & 19.17 & 32.60 & 178.44 \\
\hline 31 & Kalma & Quality parboiled rice & 21.32 & 36.07 & 150.72 \\
\hline 32 & Tulsiphenu & Quality parboiled rice & 18.68 & 23.27 & 147.67 \\
\hline 33 & BR-34 & Quality parboiled rice & 20.72 & 24.63 & 157.76 \\
\hline 34 & Parbatjira & Small grain, high aroma & 19.33 & 28.73 & 190.79 \\
\hline 35 & Chinigura & Quality parboiled rice & 21.38 & 23.93 & 196.75 \\
\hline 36 & Kalijira & Small grain, high aroma & 15.63 & 21.40 & 113.69 \\
\hline 37 & Tulaipanji & Small grain, high aroma & 15.17 & 37.00 & 104.59 \\
\hline 38 & Kalijoha & Small grain, high aroma & 16.57 & 20.77 & 126.12 \\
\hline 39 & IET13544 & Small grain, high aroma & 20.82 & 22.17 & 181.52 \\
\hline 40 & Chinikamini & Small grain, high aroma & 14.37 & 27.87 & 172.33 \\
\hline 41 & Kedargouri & Quality parboiled rice & 20.65 & 25.27 & 193.68 \\
\hline 42 & Dudkhas & Quality parboiled rice & 14.94 & 40.57 & 144.61 \\
\hline 43 & Dadshal & Quality parboiled rice & 17.30 & 44.47 & 120.00 \\
\hline 44 & Gangajali & Quality parboiled rice & 16.77 & 33.70 & 116.79 \\
\hline 45 & Kanakchur & Quality parboiled rice & 16.77 & 20.93 & 156.76 \\
\hline 46 & IR-36 & High yielding variety & 16.17 & 11.90 & 126.11 \\
\hline 47 & IET-4094 & High yielding variety & 17.37 & 13.47 & 110.73 \\
\hline 48 & IET-4786 & High yielding variety & 17.90 & 13.33 & 104.49 \\
\hline 49 & CNHR-7 & Hybrid variety & 18.27 & 11.57 & 104.67 \\
\hline 50 & PHB-71 & Hybrid variety & 15.23 & 11.77 & 107.55 \\
\hline \multicolumn{3}{|c|}{ Grand mean } & 19.4782 & 36.121 & 143.83 \\
\hline \multicolumn{3}{|c|}{$\operatorname{SEm}( \pm)$} & 0.7051 & 0.7684 & 0.1953 \\
\hline \multicolumn{3}{|c|}{ LSD (0.05) } & 2.1333 & 2.2056 & 0.4868 \\
\hline
\end{tabular}


Fig.1 Diagnostic characters of fifty rice genotypes
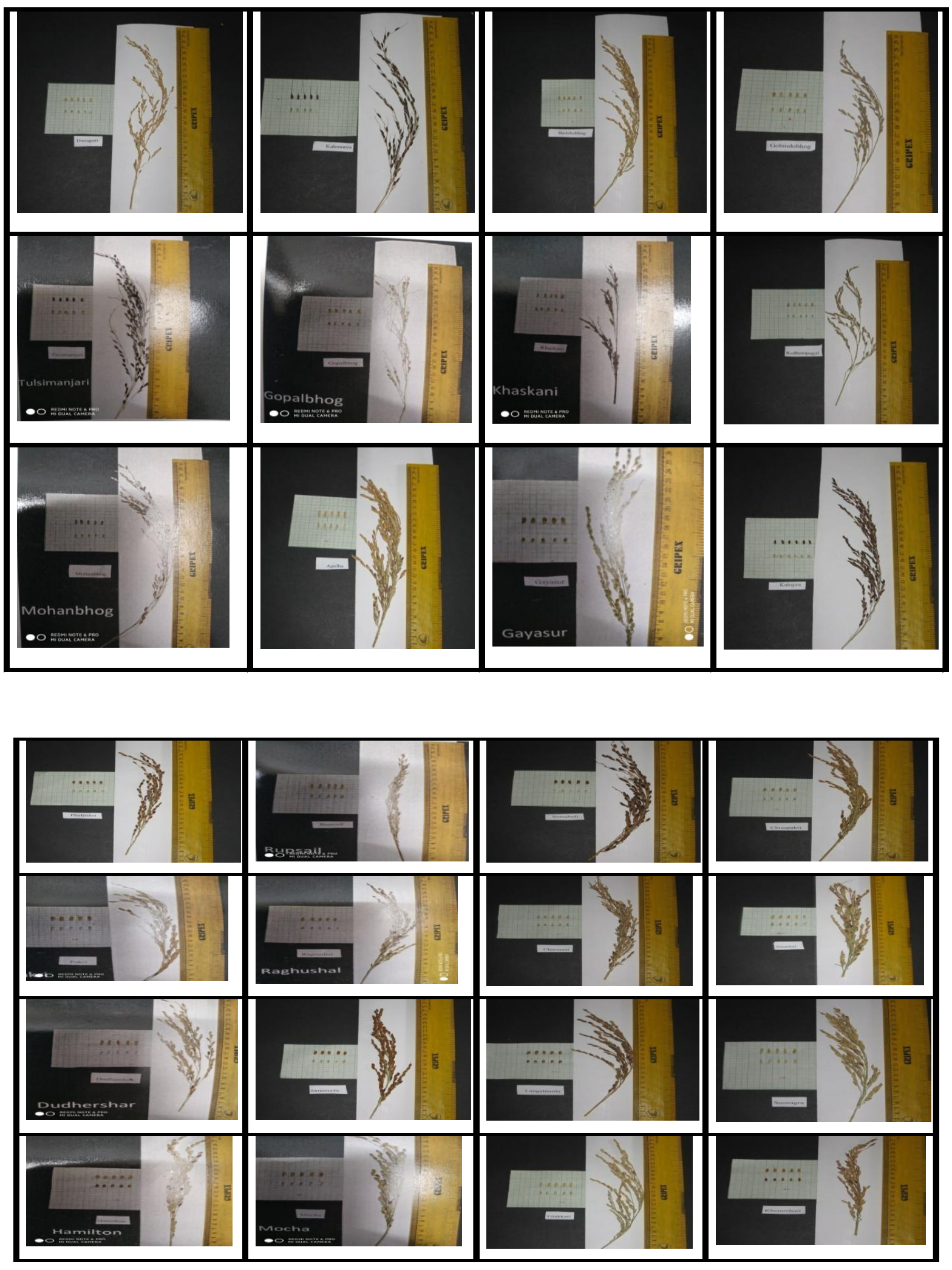

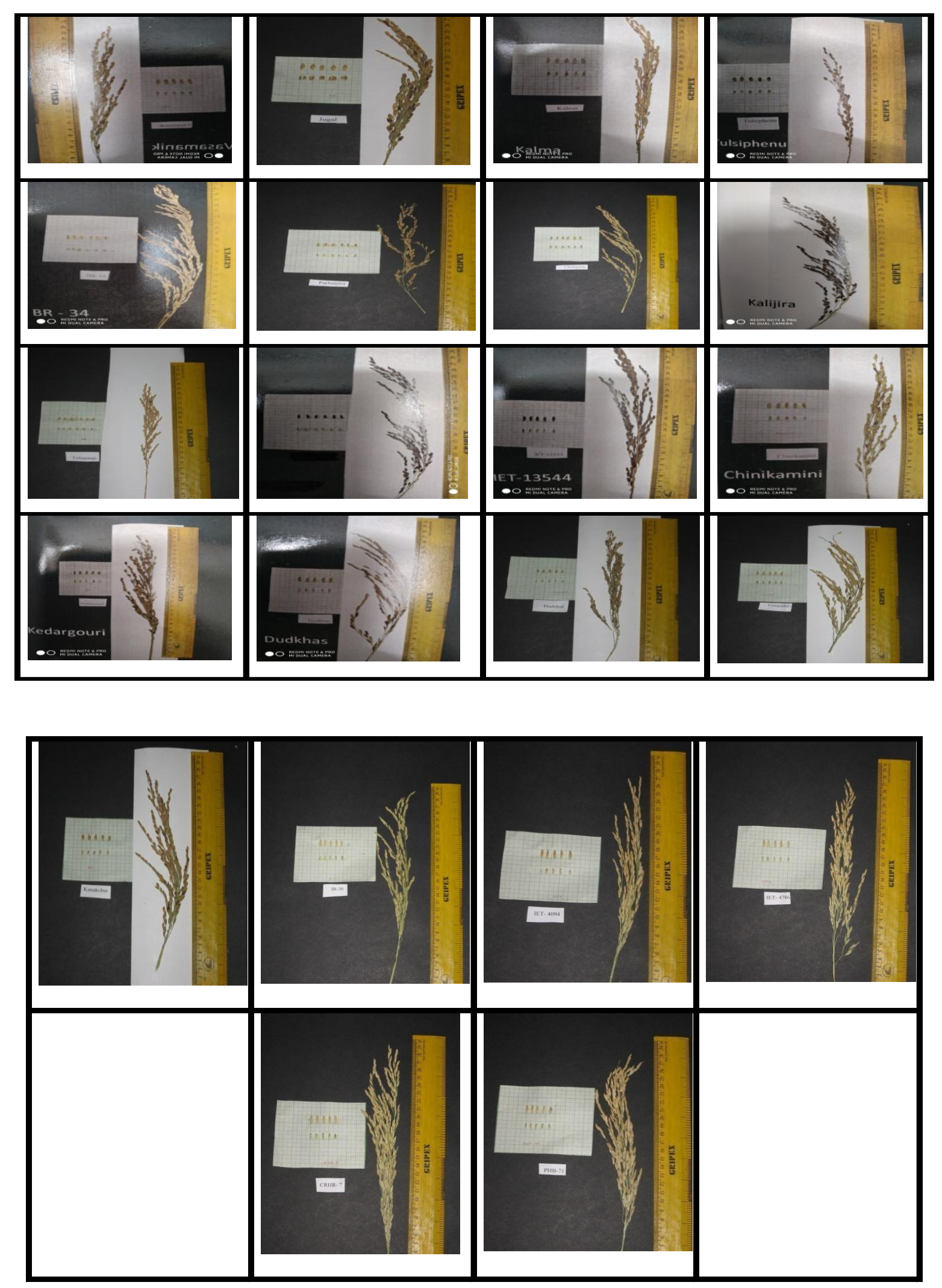
The current prevalence of milled rice on the market decreases the rice's nutritional value and essentially turns it into a simple carbohydrate food. Therefore, in addition to developing more nutritious varieties, realization of the benefits of eating brown rice should be uplifted among rice consumers (Bordolui et al., 2006). Such a combined method would ultimately outcome in a sustainable enhancement of the essential nutrient supply in rice-based diets. So we have to conserve the traditional rice genotypes which have the high nutritional values for further breeding programme.

From this experiment it was found that highest seed length in Agulha, seed breadth in IET13544 and seed thickness in Chinigura than other genotypes. Seed length varied from $5.13 \mathrm{~mm}$ to $10.13 \mathrm{~mm}$, the breadth varied from $1.50 \mathrm{~mm}$ to $3.40 \mathrm{~mm}$. The lowest seed length was recorded in Parbatjira and highest in Agulha and lowest seed breadth was recorded in Danaguri and highest in IET13544. Seed thickness varied from 1.45 $\mathrm{mm}$ to $2.54 \mathrm{~mm}$ and it was lowest in Danaguri and highest in Chinigura. Seed lengths, seed breadths and seed thicknesses were highly significant difference between the genotypes. The kernel length ranged from $4.13 \mathrm{~mm}$ to $7.70 \mathrm{~mm}$. It was highest in Agulha and lowest in Danaguri. The kernel breadth varied from $1.37 \mathrm{~mm}$ to $2.92 \mathrm{~mm}$. Highest was recorded in Dudkhas and lowest in Danaguri. Kernal thickness ranged from 1.30 $\mathrm{mm}$ to $1.89 \mathrm{~mm}$ and it was lowest in Danaguri and highest in Kalijoha. The genotypes Agulha, Dudkhas and Kalijoha had highest kernel length, kernel breadth and kernel thickness respectively among the genotypes. Here also these three parameters were highly significantly variation among the genotypes. These seed characters are comparable with the seed length of present day farmer chosen semi dwarf varieties. With respect to seed yield, the high yielding and hybrids score the highest performance. It was recorded in the hybrids $C N H R 7$ and $P H B 71$ followed by the 3 high yielding varieties. Among the indigenous genotypes, Chamarmani $\left(550 \mathrm{~g} \mathrm{~m}^{-1}\right)$ was the best yielder followed by Jugal $\left(540.67 \mathrm{~g} \mathrm{~m}^{-1}\right)$, similar type of result was observed by Bordolui et al., 2015. The genotypes had almost the same performance in both the years though the genotypes differed significantly. It shows the least environmental influence on seed yield. Normally seed yield fluctuates but here depending on the present investigation less environmental influence as most of the genotypes were traditional genotypes.

In view of nutritional deficiency in diet, it is essential to find out high content of nutrients (like $\mathrm{Fe}, \mathrm{Zn}$ and $\mathrm{Ca}$ ) in indigenous rice genotypes. The genetically modified (GM) rice is too costly and it is very difficult for poor people to take their diet daily. There are some indigenous rice varieties which content high amount of $\mathrm{Fe}, \mathrm{Zn}$ and $\mathrm{Ca}$. the farmers are no longer interested to cultivate these low yielding and long duration varieties due to high ingress of high yielding varieties. It has been slowly realized that the green revolution package in developing country like India has not only replaced much of the indigenous crop varieties, but has mostly benefited the rich farmer, because the cost of high inputs fertilizer, pesticide and irrigation which remain beyond the means of poor, marginal and even economically middle group of farmers. The cost benefit ratio of growing HYV drastically has changed. The rice growing farmers have to look for alternative high value rice which can give them at least sustainable dividend. Another looming on them has been the biopiracy of local rice genetic diversity with corporate control of the seeds market, which is likely to destroy the crop diversity and eventually food security (Shiva, V. 2000). The issue of "intellectual property right" is not clear to many including 
farmers but ahead a blunt attempt to establish exclusive marketing rights even in the country of origin of the genetic material has been evidence. Significantly highest zinc content was found in Raghushal (26.45ppm) followed by genotypes Kalonunia (26.42ppm), Pakri (25.48ppm), Langalmuthi (25.10ppm), Hamilton (23.47ppm), Chamarmani (23.47ppm), Suanagra (23.25ppm), and Dudherswar (23.05ppm), while lowest was in Chinikamini (14.37 ppm) preceded by genotypes Gayasur (14.40ppm), Fulpakri (14.73ppm), Dudhkhas (14.97ppm), Tulaipanji (15.17ppm), PHB-71 (15.23ppm), Agulha (15.47ppm), Tulsimanjari (15.60ppm) and Kalijira (15.63 ppm).

It could be revealed that the genotypes varied significantly amongst it selves for iron content: highest value was recorded for Sonajhuli followed by genotypes Hamilton (65.73ppm), Langalmuthi (64.97ppm), Rupsail (64.83ppm), Chamarmani (63.60ppm), Jamainadu (58.53ppm), Suanagra (56.60ppm), Chinapakri (56.60ppm) and Gayasur (56.40 ppm). Lowest iron content was observed in PHB-71 preceded by $C N H R 7(11.57 \mathrm{ppm}), \quad I R-36$ (11.90ppm), IET-4786 (13.33ppm), IET-4094 (13.77ppm), Gobindabhog (21.00ppm), Agulha (21.13ppm) and Kalijira (21.40 ppm).

With regard to calcium content among these rice genotypes, it was ranged from $104.49 \mathrm{ppm}$ to $196.75 \mathrm{ppm}$. Maximum value of calcium was found in Chinigura followed by genotypes Kedargouri (193.68ppm), Parbatjira (190.79ppm), Vasamanik (187.93ppm), Dudheswar (187.63ppm), IET13544 (181.52ppm), Jugal (178.44ppm), Tilakkati (175.58ppm), and minimum was in IET-4786 (104.49ppm) preceded by Tulaipanji (104.59ppm), CNHR7 (104.67ppm), PHB-71 (107.55ppm), IET4094 (110.73ppm), Danaguri (110.86ppm), and Kalojira (110.90 ppm). The genotypes varied highly significant for calcium content in rice. It is suggested that these group of genotypes can be utilized as well adopted high value rice. The commercial potential of these genotypes are encouraging.

In conclusion among 50 genotypes, the indigenous aromatic and non-aromatic genotypes had better performance for most of the phenotypic traits but they were long duration genotypes with low yield. The high yielding and hybrids score the highest seed yield with moderate duration. However, almost all genotypes were significantly different. But it is interesting to note that the indigenous genotypes were rich in micronutrient. Highest iron, zinc and calcium contents were found in Sonajhuli, Raghushal and Chinigura respectively. It is suggested that the indigenous genotypes having considerably high micro-nutrients like Fe, Zn and $\mathrm{Ca}$ content may be considered as high value rice genotypes. The potentiality of these genotypes may be exploited commercially.

\section{References}

Biswas S., Bordolui S.K., Sadhukhan R. and Chattopadhyay P. 2020. Study the Effect of Staggered Sowing of Hybrid Rice in New Alluvial Zone. Int. J. Curr. Microbiol. App. Sci. 9(04): 1814-1826

Bordolui S.K., Chattopadhyay P. and Basu A.K. 2018 Evaluation of some small seeded aromatic indigenous genotypes for commercial utilization as high value rice. International J. of Minor Fruits, Medicinal and Aromatic Plants. 4 (1): 40-43.

Bordolui S.K., Chattopadhyay P. and Chandra P. 2006a. Comparative performance of low land indigenous rice genotypes in Gangetic Alluvial Zone. Journal Crop and Weed. 2: 33-36.

Bordolui S.K., Sadhukhan R. and Chattopadhyay P. 2015. Participatory 
evaluation of some folk rice genotypes. Journal Crop and Weed. 11(2):59-62.

Bordolui, S.K., Chattapadhyay, P. and Chandra, P. 2006b. Morphological characters of some conserve folk rice genotypes. Environment and Ecology 24 (2): 421-417.

Chakraborty, A., Nandi, D., Bordolui, S.K. and Mahato, M.K. 2020. Biofortification - a tool to fight nutrient deficiency. Novel International J. of Science \& Technology .1 (1): 1-14

Hsieh H.M., Liu W.K., Huang P.C. 1995. A novel stress-inducible metallothioneinlike gene from rice. Plant Mol Bio. 28 :381 -389.

Jackson M.T. 1997. Conservation of rice genetic resources: the role of the International Rice Genebank at IRRI. Plant Mol. Biol. 35: 61-67.

Lettington R.J.L. 2001. The good, the bad and the ugly: a southern perspective on the relationship between TRIPs article 27(3)(b) and Article 15 of the CBD. In Broggio, M. \& Kaukab, R. eds. The Geneva documents.Proceedings of the Workshops on TRIPs, CBD and the International Undertaking. Florence, Italy, IstitutoAgronomico per l'Oltremare.

Pasamontes L., Haiker M., Wyss M., Tessier M. and Van Loon A.P.G.M. 1997. Gene cloning, purification, and characterization of a heat-stable phytase from the fungus Aspergillus fumigatus. Appl Environ Microbiol. 63 :1696 1700 ,

Spence M.J., Henzl M.T. and Lammers P.J. 1991. The structure of a Phaseolus vulgaris complementary DNA encoding the iron storage protein ferritin. Plant Mol Biol. 17 :499 -504.

WHO 1992. National Strategies for Overcoming Micronutrient Malnutrition. Document A45/3. Geneva: World Health Organization.

\section{How to cite this article:}

Sanjoy Kumar Bordolui, R. L. Moharana and Chattopadhyay, P. 2021. Morphological and Nutritional Evaluation of Some Conserved Folk Rice Genotypes to Fight Back Against Micronutrient Deficiency. Int.J.Curr.Microbiol.App.Sci. 10(01): 2038-2048. doi: https://doi.org/10.20546/ijcmas.2021.1001.235 